\title{
Estonian Language of Technology as a Factor Supporting the Evolution of Engineering Thinking
}

\author{
Vahur Mägi \\ Tallinn University of Technology, \\ Research and Development Division, \\ Tallinn University of Technology Library \\ Ehitajate tee 7 /Akadeemia tee 1 , \\ Tallinn 12618, Estonia \\ E-mail: vmagi@lib.ttu.ee
}

\begin{abstract}
Casual mention of teaching technology subjects in Estonian schools dates back several centuries. Navigation and construction were among the earliest professional skills that were taught. As both of them required mathematical thinking skills, teaching the subjects was usually accompanied by explaining the principles of mathematics. The first technology book in Estonian was published about two centuries ago and it dealed with geodesy. The earliest Estonian glossaries of technological terminology were published in the fields of physics and chemistry. The rise of Estonian as a language of higher education and science in the country came about in the 1920 s and 1930s. Faculty members of the Tallinn School of Technology then published the first textbooks composed in the Estonian language for students of technology. The Estonian Society for Technology and the Estonian Association of Engineers became seriously involved in linguistic activities. Together with the Vocational Teachers' Assembly of Tartu they published an illustrated technology glossary for machinery and tools terms. It was followed by a glossary of construction and building terms, compiled under the lead of the University of Technology. In addition, journals of technology introduced innovations in the lexicon of technology to the general public. The postwar period in the development of the lexicon of technical terms was of little significance at first. A surge in language creativity could be detected in the 1960 s, when terminology became a target of constantly growing attention to the development of technology lexicon. Series of technology glossaries were published. This tendency has continued to this day.
\end{abstract}

Keywords: language of technology, lexicon of technical terms, linguistic creativity, technology, terminological dictionaries 
Estonians have been characterized by their aptitude for technology and technical craftsmanship since the dawn of ages. Archaeological findings have shown that Estonians mastered metalsmithing by as early as the Bronze Age. Their subsequent acquaintance with iron, about two thousand years ago, led Estonians to employ the iron ore smelting process on their own. The largest ancient iron smelting site in Estonia was located in the parish of Mustjala in the northern part of the island of Saaremaa. The emergence of the blacksmith's craft in this region dates from the same period. The local inhabitants were knowledgable in the use and qualities of timber. As littoral people they were skilled in hewing watercraft. Vessels built by the inhabitants of Saaremaa were regarded with genuine appreciation by the chronicler Henricus Lettus. The boats were allegedly swift and steady, and the men appeared to be competent seafarers. Estonian limestone architecture originates some time in the $13^{\text {th }}$ century, as settlers from the west brought along their methods for burning lime and using lime mortar. Owing to the lack of resources of limestone suitable for masonry work, the inhabitants of southern Estonia acquired techniques for burning and laying bricks. The precise date of the appearance in this area of waterwheel, one of the most sophisticated machines of its time, has so far not been established. It certainly happened prior to the arrival of western conquerors. The Danish Census Book, or Liber Census Danice (1219-1220), already included a list of watermill sites on the Jägala River. Further evolution of technological thought brought about the utilization of water power by means of waterwheels in a steadily growing range of new production areas: sawing boards, milling textiles, hammering copper, etc.

The first qualified masters arrived in Estonia together with German merchants, who had been invited from Visby by brethren of the Teutonic Order. All through the Middle Ages, the spreading of technological knowledge and professional skills was carried out by various merchant and craft guilds. Guilds were responsible for professional training and work accuracy. Journeymen's obligation to travel to distinguished handicraft centres and workshops in Europe and present a masterpiece conforming to strict requirements as a precondition for the promotion of master's rights facilitated the swift arrival of up-to-date technological innovations in Estonia. The guild system became ever so solidly rooted in Estonia that it turned out to be a stumbling block in the path of the later transition to manufacturing production, which at that time represented novel technological thinking. Due to the disappearance of guild constraints, in the $18^{\text {th }}$ century it became necessary to find solutions for associating school instruction with vocational training and, in this way, spread technical skills. 


\section{The first school textbooks containing technological knowledge}

Indirect mentions of teaching technology subjects at local schools can be dated back to as early as the first half of the $18^{\text {th }}$ century. For example, the Albu Seminary in Järva County offered training in building skills, whereas the school of calculus in Tallinn was specialized in teaching navigation. In 1647, Gebhard Himsel, professor of mathematics at the Gymnasium Revaliense, published a textbook by the title Florilegium fortificatorium tripartitum oder Kriegs Baw Kunst. The book discussed city planning and buildings, provided information on the principles of perspective drawing and demonstrated the application of rules governing military architecture to fortification works. Since building work requires mathematical thinking, the textbook included several appendices with chapters covering the basic principles of geometry and trigonometry. The aforementioned fortification textbook thus additionally appears to be the first mathematics book published in Estonia (Lumiste, 1968). Heinrich Julius Woltemate, who followed Himsel as the teacher of mathematics at the Gymnasium Revaliense, likewise published a book which was dealing with conduct of war and construction of field fortifications, and was similarly intertwined with mathematics.

Dramatic changes in the national self-identification of Estonians started to emerge in the middle of the $19^{\text {th }}$ century. The native language gained in importance, as language usage regulation enjoyed considerable freedom in the second half of the century. A standardized Estonian language was adopted to replace the hitherto used two varieties. The new Finnish-style system of spelling also facilitated the spread of literary language, as it was considerably simpler and less contrived compared to the previously used German-style spelling. The vocabulary was enriched with new terminology to describe contemporary life. Friedrich Ferdinand Meyer compiled a yet another book of mathematics which was published under the title Arwamisse ja rehkendamisse ramat ('Calculus and reckoning') in 1852 in Tartu. Bearing in mind the evolution of technological thinking in Estonia, we should regard the book's 24-page appendix with a separate title Arwamisse-ramato lisa. Wälja-moödust ehk Ma-moötmissest ja Maarwust ('Appendix to calculus and reckoning: on land-surveying and statistics') as of even greater significance than the main body of the text. It could be rightfully considered the first milestone in the history of Estonian technology books (Mägi, 2001). When the University of Tartu was reopened in 1802, the Chair of Agricultural Technology and Architecture was established within the 
Faculty of Philosophy with a view to the furtherance of farming. Among the principal courses of the faculty, led by Professor Johann Krause, mention should be made of agricultural technology. Lectures on physics were delivered at the Faculty of Theoretical and Experimental Physics, although originally exclusively to medical students. The Rector Georg Friedrich Parrot himself was engaged as professor of physics and lectured on general physics and solid state physics. His specific subjects included electricity, magnetism and galvanism, complemented by meteorology and physical geography as additional courses. He is also given credit for the establishment of the first Cabinet of Physics in Tartu (Mägi, 2007). Parrot's articles were drawn from his own research and were mostly implementation-oriented: illuminating rooms, constructing ship masts, making gunpowder.

A considerable variety of factual information bearing on technological innovations found its way into the printed word. Technology-related issues were rather copiously represented in Ma-ilm ja mónda, mis seal sees leida on ('The world and everything inside it', 1848-1849), a popular collection by Friedrich Reinhold Kreutzwald which was aimed at the general public. While writing the stories the author had borne in mind the Germans' Das Pfenning-Magazin, which in turn was drawing on the British The Penny Magazine. Owing to this specific fact, Estonians received technology news in these very topics that were considered worth introducing on a broader scale elsewhere. The collection included stories aimed at acquainting a reader with the art of printing, papermaking, steamship, steam car, railway, suspension bridge, tunnel construction under the Thames, etc. Splendid illustrations copied from the German publication greatly contributed to the understanding and legibility of the text, while the greatest difficulties Kreutzwald had to deal with were related to the vocabulary. Due to the lack of appropriate terms, the author felt a constant pressure to figure out new circumstantial definitions for sophisticated concepts.

Textbooks played an important role in communicating technological knowledge to the common people. With the emergence of teaching physics in parish schools in the mid-19 $9^{\text {th }}$ century, the need for Estonian-language physics textbooks became evident. A physics textbook entitled Wisika, ehk óppetus lodud asjade issewisidest ja wäggedest ('Physics or the study of the ways and forces of all things created,' 1855) was published by Johann Georg Schwartz as the sixth volume in his eight-volume series of school textbooks, which was issued in 1852-1861. It is difficult to establish now whether the textbook was an original work or it was compiled on the basis of some foreign-language textbook. In any case, 
it was a good effort at communicating knowledge of physics in the Estonian language. Besides explaining natural phenomena the book offered practical examples of their applications in technology. Due to a lack of technical terms, popular language was used to describe physical phenomena. When compiling the following physics textbook Wiisika-öpetus. Koolidele ja iga teaduse nóudjalle ('Physics: for schools and people interested in the sciences,' 1881), the author Jakob Tülk, who had studied philosophy, mathematics, astronomy and chemistry in Geneva, Paris and Strasbourg, examined and followed the example of French and German textbooks. While the presentation of the subject matter is somewhat clumsy, the book as a whole may be considered gratifying as to its linguistic aspect. The first book in the Estonian language to enfold knowledge about chemistry was a reader by George Gottfried Marburg (1805). The author mentions in the preface that when compiling the book he was specifically bearing in mind peasant children and their schoolmasters. Above all, the book offered readers useful hints on husbandry, as land cultivation was the major occupation of the country people (Deemant, 1976). The first book specifically devoted to tillage was a handbook for farmers, Pöllomehhe nöuandja, published in 1866. This anonymous work had a considerable guiding and formative effect on Estonian farmers. Besides providing information on agronomy, mention is also made of the need for agricultural societies. Estonian agricultural societies, which were established all over the country following the example of German societies from 1870 onwards, eventually developed into highly influential associations, setting themselves vastly broader objectives than purely agricultural functions (Aarma, 2009). A growing number of Estonian-language journals and books aimed at introducing agricultural innovations as well as developing agricultural terminology were published largely thanks to the support of these societies.

\section{The spread of technological knowledge and establishment of engineering schools}

The first educational institutions of technology to operate for a longer period were schools of navigation, the starting of which laid the foundation for the continuing technology education in Estonia. The earliest school of navigation was founded in Heinaste, and was succeeded by schools in Narva, Paldiski, Käsmu and Kuressaare. Students primarily entered schools of navigation with an aim to swiftly pass the introductory theoretical programme required for professional examination. For this reason, their curricula very strictly included only those 
subjects that were absolutely necessary for a seaman-namely, mathematics, physics, nautical astronomy, steering of a ship, marine engineering. The basics of steam mechanics were included at a later stage. Schools of navigation were in urgent need of specialized textbooks. Because of a lack of such books, the task of communicating the subject as well as advancing the professional terminology was fully imposed on teachers (Sirk, 1983, p. 64). Another consequential step in the development of technology education in Estonia was the establishment of a school of railway technology in Tallinn.

The first comprehensive overview of chemistry was written in 1887 by Jaan Kompus, a graduate of the Cimze Seminary in Valka The press-ready manuscript remained unpublished because of the ban on Estonian-language schools as well as textbooks at that time by the Russian tsarist government. A permission to reinstate Estonian as a language of teaching in the first and second years of elementary school was not obtained until 1905, and from then on the establishing of Estonian-language private schools also became permissible. There arose an urgent need for native-language textbooks and technology literature in exact sciences. The first Estonian-language chemistry primer, compiled on the example of English-language sources, was published in 1908.

Estonian Literary Society had an important role in the development of Estonian language of technology, as its language committee was the earliest association to draw attention to the future of professional lexicon. Cultural and educational figures in the society emphasized the need to start deriving terms in all subject areas without delay, because publishing either native-language textbooks or scientific literature would otherwise be unthinkable. Carrying on a controversy over the objectives of technical language development the linguist Johannes Voldemar Veski on every occasion insisted on reckoning with the idiomatic usage of the language as well as with logical distinctness and clarity. Vagueness of expressions, superfluous liberty in the application of terms and adopting a negative attitude towards technical terms could not be tolerated especially as far as scientific terminology was concerned. On the initiative of the literary department of the Estonian Society for National Education, together with the language committee of the Estonian Literary Society, a series of discussions on linguistic issues were held during 1908-1911 with a view to elaborate the general principles for regulating the usage of language. 


\section{Estonian undergraduate students and the expanding intellectual community}

In the first years of the $20^{\text {th }}$ century the number of Estonian undergraduate students was estimated to be about a couple of hundred. A perceivable shift could be detected in the specialty preferences among the scholarly community, showing a growing tendency to favor the sciences. Riga was the nearest place to obtain a diploma in engineering. Other subjects that could be studied there besides technology included architecture, geodesy, agriculture and commerce. When the polytechnic school in Riga was given the rights of a public institute of technology in 1896, a steep increase in the number of Estonian students could be seen. Newly opened secondary science schools in Tartu and Tallinn obviously played a certain role. Riga was primarily chosen as a place to study abroad by young agrarian men from the more prosperous areas in southern Estonia. Young men from Tallinn and northern Estonia chose to study technology at St Petersburg, where they had a choice between institutes of road engineering, technology, electrical engineering, mining and forestry. In 1907, the list was supplemented by a polytechnic institute. Next to the university in St Petersburg, the polytechnic institute became the most highly regarded establishment of higher education among the Estonians. Quite a few venturous Estonians even dared to move further on, to Western Europe, primarily Germany and France. Among Estonian students of technology the preferred places to pursue education in those countries were the universities of technology in Darmstadt and Karlsruhe, the engineering academy in Wismar, the technical school in Strelitz, universities in Toulouse and Nancy. As many as a hundred or so Estonians had acquired engineering education by 1915, whereas the number of students studying technology subjects at the time was virtually the same.

The Estonian Provisional Government convened in Tallinn in the summer of 1917. The governor of the Province of Estonia Jaan Poska invited a civil engineer Ferdinand Peterson to head the Technology Department in the Province Government under formation. The whole set of issues related to the building and maintenance of highways and local communication networks as well as supervision over large-scale construction works and industry were designated to the department. For the very first time, the formulation of Estonia's technology policy was confided to engineers from among the natives of the country. A critical breakthrough in the development of Estonian technology education came with the founding of the Estonian Technical Society (ETS) in the autumn of 1917. 
The objectives of the society included spreading knowledge of technology and preparing skilled manpower for the technology sphere. The state of affairs regarding Estonian lexicon of technical terms and ways to develop it were immediately brought up for discussion at its first general meeting. The Education Committee of Tallinn suggested that the society should open a technical school. Whilst the German occupation authorities abstained from providing an operating licence to an Estonian-language educational establishment, the only possible measure within reach was to set up special technical courses in the society. The courses commenced on September 17, 1918 in six fields of study: architecture, civil engineering, electrical engineering, hydro technology, marine engineering and mechanical engineering. Right from the start, training was carried out in the Estonian language. In spring 1920, the legislative delegation of the Constituent Assembly approved the statutes of the Tallinn Technical School, whereby the school was accredited as a public educational institution. The school was designated as a higher education institution by the Business License Act concerning engineers, architects and technicians (1923).

Estonian-language higher technological education did not come from nothing in 1918. Estonian-language terminology, although brought into play in a rather uncoordinated manner under haphazard circumstances, had largely been generated at earlier times. Technology books had been published long prior to the establishment of Estonian independence. Thus, several textbooks and handbooks covering various areas of technology were published during the 1870 s and 1880s, such as comments to promote road construction (Móni sóna meie maantee tegemise kergituseks, 1873), the regulations of Baltic railroad guards (Balti raudtee vahtide säädus, 1877), instructions on the use and maintenance of steam-powered vehicles and threshers (Juhatused kuida lokomobilid ja rehepeksumashinad tarvitada ja hoida on, 1889), and others. An ever-growing number of books about technical disciplines was published between 1911 and 1917, among these books on electrical engineering, machinery, heat engineering as well as glossaries of chemistry and physics.

The emergence of Estonian-language chemistry literature and delivering chemistry lectures introducted the demand for a unified terminology in chemistry. As the majority of authors compiled their textbooks relying upon source materials either in Russian or German, the Society of Estonian Students in St Petersburg decided that their chemistry dictionary, Keemia sonnastik, would incorporate terms in the Russian-German-Estonian languages. Published in 1914, it included a glossary supplied with a short overview of morphology to help deriving new chemistry 
terms. Several physics textbooks came out shortly before the onset of the First World War. The process of regulating physics terminology was also started and for this purpose a respective committee was formed within the Estonian Students' Society in Tartu. The unification of physics terminology at a broader scale was carried out during the First Congress of the Teachers of Physics and Mathematics in 1917 in Tartu.

When Estonian was introduced in Estonian schools as the language of instruction, teachers were initially forced to cope with physics terminology on their own. Physics teachers Juhan Lang and Osvald Sulla initiated the standardizing of the existing terminology in the field. Johannes Voldemar Veski assumed responsibility for editing the dictionary from a purely linguistic point of view. The book became available for readers at the end of 1919. The authors strived to incorporate each and every term that one would encounter in high school physics programme and even a selection of words from respective university courses. Evald Maltenek, an engineer educated in Riga, later thoroughly revised the dictionary (Mägi, 1987). While agreeing that Estonia was lacking a science system as well as the language of science of its own and that the formation of the former largely depended on achievements in the latter, Maltenek cautioned against introducing new words into the language. In order to avoid the accumulation of dissonance in the language through establishing links between widely divergent concepts, he presented three principles for building vocabulary in science and technology: (1) the meaning of a word should derive from vernacular language, (2) the nuances of meaning must be distinctly perceptible, and (3) the existing word stems should form the basis for new derivations. With their dictionary, Lang and Sulla added the standardization of terminology in physics and technology considerable impetus (Lang, 1976). Most of Maltenek's remarks were approved at the $2^{\text {nd }}$ Congress of Teachers of Mathematics, Physics and Cosmology in spring 1921 in Tartu and were put to use as the terminological basis for schools. Estonian translations of basic chemistry concepts were introduced in a schoolbook by Otto J. Kiesel (1922). 


\section{The role of Estonian Technical Society in the development of terminology}

Purposeful development of the Estonian language of technology was initiated by the Estonian Technical Society (ETS). In spring 1919, the society decided to start issuing a journal of its own. A linguistic committee was established within the society with an aim to develop terminology and one of the further objectives was to publish a general technical glossary. The construction of technical terms was subsidized by the publishing co-operative 'Rahvaülikool. Technical neologisms reached the public through the journal Eesti Tehnika Seltsi Ajakiri. The journal additionally published highly popular columns for language disputes, and the chance to participate was used by many (Mägi, 1989). The positions of the linguistic committee were not always taken into consideration, especially when they were not adequately formulated opinions. A heated debate arose around the term for oil shale. Linguists and natural scientists were consulted with to find a more appropriate term-one that could not be translated into other languages. At a later stage the linguistic committee was disbanded and the responsibility for linguistic activities was transferred to the Board of the ETS, while experts of special fields and linguists were consulted with as occasion required. Primary attention in enriching terminology was paid to three areas: electrical engineering, geodesy, and railway engineering (Hacker, 1920).

The total number of new technical terms that were introduced through the mediation of the ETS amounted to a couple of hundred. The society also initiated the compilation and publication of the first Estonian-language technology handbook, even though only the first volume, dedicated to mathematics, actually became available for readers. The following technology handbook targeted at the general public was published by the Tartu School for Industry and Business Students. Industry was searching for new ideas, since the previously well-established village system had been shaken up by a land reform. Within a couple of years, tens of thousands of new farmsteads had been established, all of which needed ironware as well as buildings. The main department of the Ministry of Agriculture called for an open contest to obtain farmstead design plans. The prize-winning projects were published in a collection Taluehitused ('Farm buildings,' 1921), which remained an important source reference for the countryfolk in Estonia over a long period of time, succeeded in influencing the Estonians' understanding of a farmstead and farm buildings, and thereby shaped the future appearance of Estonian villages. 
Results of the efforts made by the ETS towards the acquisition of native language vocabulary in technology and establishment of technological literature became visible in the second half of the 1920s, when lecturers of the Tallinn Technical School published one after another a number of high-level textbooks in analytic geometry, electrical engineering, hydraulics, technical chemistry and thermodynamics. The most influential among them was a six-volume book on technical mechanics, Tehniline mehaanika by professor Ottomar Maddison. In terms of its scope and bulk, this book has remained insurmountable up to now. The core vocabulary of hydrology and hydraulics was largely constructed by the engineer August Wellner, alongside his main occupation as head of the Inland Waterways Office. Similarly, the ETS started to publish the first Estonianlanguage technology handbook, of which only the first volume discussing mathematics became available for readers.

The rise of Estonian to a language of higher education and science was actualized in the 1920s and 1930s (Kübarsepp \& Mägi, 2011). The Estonian Association of Engineers (EAE) joined in the lexicographic activities, making a growing contribution. The mining section of the association published a terminological dictionary of the mining industry. Evald Maltenek, lecturer at the Tallinn Technical School and a well-known radio constructor, contributed to updating and enhancing the terminology of radio technology.

\section{Teachers of Tartu schools regulating the usage of technological terminology}

The lack of standardized terminology for technology caused difficulties in schoolwork, especially with regard to teaching special subjects in technology at vocational schools. A circle of vocational school teachers in Tartu thus introduced an idea to compile a glossary of technology terms, which was intended to serve as a basis for teaching technology subjects at schools and would also contribute to the normativization of technology terms in everyday language use. Heads of technology-oriented vocational schools supported the idea and so did the Ministry of Education and Social Affairs on the initiative of the education adviser Johannes Kiivet.

In 1930, the Vocational Teachers' Assembly of the Tartu Association of Teachers established a committee for terms in technology. It was declared the Nationwide 
Committee for Technical Terminology by the First National Congress of Vocational Teachers and was assigned the task to compile technical glossaries in as many fields of technology as possible. The committee found it necessary to publish at least five dictionaries: on machine parts and tools, industrial equipment and handling operations, building structures, women's handicraft, and electrical engineering. The provisional plan of action was drawn up under the direction of Mihkel Vellema, head of the Tartu School for Industry and Business Students, and was afterwards sent to prospective co-workers for consideration. SchlomannOldenbourg's Illustrierte Technische Wörterbücher served as its basis, whereas all words of descriptive nature were dismissed. EAE's propositions were taken into consideration as the most exhaustive and substantial ones. A science committee took part in the compilation of the dictionary on part of the association, and the committee's activities in creating technical terms culminated in 1932 and 1933. The committee accomplished a commendable task by scrutinizing each and every technical term, forwarded to the EAE, that after a thorough consideration were returned to the committee for technical terms. Members of the association were kept informed with the state of affairs through the mediation of the journal Tehnika Ajakiri. The committee's task appeared more complicated than had been expected. Frequently enough, agreement had to be achieved between quite incompatible propositions. The position of the EAE on those occasions was conclusive as a rule. In the case of more drastic disputes, a representative of the EAE in the person of a mining engineer Jaan Kark, board member of the association's chemistry section, arrived at the meeting. Johannes Voldemar Veski and Manivalde Lubi participated in the work of the committee by elaborating on received propositions and identifying eligible technical terms. The first volume of the technological dictionary for machine parts and tools entitled Illustreeritud tehnika sónastik. I osa. Masinaosad ja tööriistad was published in 1933 in Tartu as Fascicle 1 of the Proceedings of the Industrial Schools' Subject Committee, comprising 1,605 terms to designate various machine parts and tools. This publication laid a solid foundation to the Estonian-language technology terminology and received positive feedback. Of the technical terms included in the dictionary, quite many have made their way to the present-day language use. 


\section{The Estonian Chamber of Engineers commences activities}

While Vellema's committee, by providing designations for machine parts and tools, had succeeded in establishing some system in the sphere of general technological lexicon, the area of civil engineering and related fields, such as building engineering physics and strength of materials, enjoyed unrestrained liberty in using terms of one's own choice. The German language was employed whenever needed. Quite a number of influential engineers had received German-language education and therefore found the use of German terms more convenient than searching for a precise equivalent in Estonian. Among other issues, for example, it was debated whether an appropriate Estonian equivalent for the German term Festigkeit designating load resistance should be tugevus or something else. In these days, Estonian builders referred to mortar in casual conversation as mörtel. Even though linguists tended to prefer the word laast, a Finnish loan, it was eventually mört, however, that got the upper hand.

The 1930s witnessed further escalation in the publishing of technology books, first and foremost thanks to the formation of the Chamber of Engineers. Next to Tehnika Ajakiri, which was issued by the Estonian Association of Engineers and the Estonian Chemists' Society, the Chamber launched a monthly of its own under the title Tehnika Köigile. The journal was aimed at introducing technology to a common reader and offered eloquently written articles in various areas, such as building, husbandry, energy-related issues, industrial equipment and navigation, additionally giving instructions on handling machinery, providing technical news and introducing recent books on technology. On top of that the Chamber of Engineers started a book series which published works on a great variety of subject content from a wide range of technology disciplines. Publishing of Estonian standards was commenced within this particular series. The Estonian Association of Engineers also started a book series of its own. The cooperative society 'Tehniline Kirjastus', established for book publishing, launched a book series by the same title. Similarly, its content was kept as comprehensive as possible. The series was edited by Albrecht Pódrus, an engineer who had graduated from the Tallinn Technical School. The compiling and publishing of handbooks, surveys and textbooks widened further. Among the emerging new areas there were mechanical engineering, mining industry, chemical industry and military technology. The EAE consistently attended international congresses of technology journalism. The Baltic Section of the Fédération Internationale de la presse technique et périodique was formed on the initiative of the EAE prior to its Paris Congress 
(1937). Facilitating the spread of technology knowledge was one of the primary objectives of the Federation and on account of this Estonia was relatively wellacquainted with contemporary foreign-language technology literature.

\section{Technological studies and terminology}

Oil shale and phosphorite became significant research objects for Estonian scientists in the 1920s. In Tallinn the respective studies were aggregated into the State Testing Centre; in Tartu an oil shale laboratory was opened at the university. The national oil shale industry at Kohtla established its own research laboratory. Technological principles for producing crude shale oil and oil shale petrol were worked out in close collaboration with research institutions in London and Zurich. A whole generation of renowned researchers in chemistry and technology were involved in the scientific elaboration of those issues. Besides problems related to chemical technology much attention was devoted to concerns pertaining to the exploitation of oil shale as an energy resource as well as utilization of oil shale burning residues. Later, in 1937, the Natural Resources Institute, formed for the better management of domestic raw material resources, was assigned a responsibility to acquire knowledge about natural resources, raw material and production in combination with finding out related scientific, technological, economic and social problems. These areas of activity required accurate terminology as well.

The language of chemistry was progressing. In 1923, the Academic Society of Chemistry set up a committee for compilation of a terminological glossary in chemistry. Close to ten thousand terms were discussed and several chemistry textbooks were published by the committee over about a decade. The most popular among them, authored by Aleksander Veiderma, came out in seven editions. The use of terminology in that textbook enables a reader to follow the explicitly continuous progress of the chemistry language. The curricula of industrial high schools focused primarily on introducing technological processes (cast iron and steel production, glass and ceramics, fuel processing) and the chemo-technological terminology. Professor August Paris published a manual of chemical analysis for a use in universities and testing laboratories. In 1937, the range of problems related to terminology formation in chemistry became a burning issue on the agenda of the Estonian Chemists' Day in Tallinn, where the intensification of efforts in that area was considered necessary. 


\section{Terminological work at the Tallinn University of Technology}

A technical terminology committee to regulate the language use of the Proceedings of the Tallinn University of Technology was initiated in 1937 upon the decision of the University Council, and Johannes Voldemar Veski was invited to participate as adviser. The activities of the committee and the decisions it made were largely influenced by his principle—all the components, schemes and rules required for the development of a language are contained within the language itself (Jürgenson, 1975). The recommended coinages were thus almost inexclusively derivatives from native-language word stems; only a few words originated from the Finnish or Swedish languages. Practical work was carried out at the Building Science and Engineering Laboratory led by Professor Leo Jürgenson (Kull, 1987). German-language technical terms to serve as the basis were selected from Schlomann's comprehensive technological dictionary, successively compared with the terms in Webster's International Dictionary and Pitman's Technical Dictionary, furnished with Estonian equivalents and forwarded, along with explanatory figures, for revision and amendments to the Ministry of Transport, the Vocational Skills Department of the Ministry of Education, the Department for Industry of the Ministry of Economic Affairs, the EAE, the Chamber of Engineers as well as to the editorial boards of the journals Tehnika Ajakiri ('Journal of technology') and Tehnika Kôigile ('Technology for all'). By the agency of the Ministry of Transportation, guidance notes of new terms were distributed to all municipal and county engineers.

The received responses widely diverged: some supported the use of foreign loans, others strictly insisted on the Estonian origin. The first reading at the beginning of 1938 produced a set of 1,600 terms for masonry, timber and metal structures as well as building materials, supplemented with figures by Arvo Veski, assistant at the Building Science and Engineering Laboratory, and published in Tehnika Ajakiri. A selected list of the published terms was thereafter issued as an offprint under the title Tehnilised oskussönad ('Technology terms'). The Estonian Association of Engineers and the Vocational Skills Department of the Ministry of Education assisted to subsidize the committee's expenses. The engineering and architectural communities in general showed a sympathizing attitude towards terminology regulation, although now and then critical voices could also be heard. Among other things, a wish for a more systematized approach was expressed as the multiplicity of synonyms tended to be confusing and for that reason some technical drawings were not unequivocally understood (Bölau, 1938). Quite a 
number of terms from among those included in the offprint, connected with the sphere of building and other areas of engineering have remained in use up to this day. This was the starting point for Professor Leo Jürgenson's pursuit of a systematic structure of terminology and strictly purposeful application of Estonian derivational suffixes that characterized his linguistic activities at a later time (Kull, 1992). Terms should be unequivocal; negligence in linguistic creation and sloppiness in linguistic communication was impermissible. Professor Ottomar Maddison's systematized treatment of his subject while lecturing on mechanics at the Tallinn University of Technology (TUT) and Veski's systematic approach towards formation of terms were combined in the person of Leo Jürgenson who formulated an integral and systematic approach to terminology.

The first decade and a half after the Second World War may be described as rather unpretentious with regard to terminology development. Regulation of terminology was carried out to some extent, but the activities were mostly restricted to borrowing from other languages or reproducing linguistic forms of other languages and creativity was but rarely encountered. This partiality was fostered by the prevailing official attitude towards language which considered language purism as of primary importance, whereas linguistic considerations were completely disregarded.

\section{The role of the Estonian Academy of Sciences in university textbook publishing}

In order to prepare textbooks for universities, the Ministry of Education started a process to set up a foundation within the Science and Art Department to publish textbooks with the view that the publishing of Estonian-language textbooks for institutions of higher education could be facilitated by means of financial support and subsidized loans. The foundation received funding from the state budget, the Cultural Endowment and other sources. The main question was how to acquire appropriate manuscripts and publish textbooks that would be affordable for students. Science publications applicable for textbooks were issued by the publishing house 'Akadeemiline Kooperatiiv' .

Universities submitted their suggestions for textbook publishing to the Ministry in the autumn of 1938. The proposal presented by the Tallinn University of Technology comprised 15 books, of which 11 were included in the list of 
priority. As a result of subsequent negotiations, the authority to decide upon the publication of textbooks for higher educational establishments was delegated to the newly established Estonian Academy of Sciences (Veiderma, 2006). For this purpose the General Assembly of the Academy decided to form a fivemember committee. In the committee, the Tallinn University of Technology was represented by Vice Rector Vladimir Paavel, who was, in addition, elected the deputy chairman of the committee at a later time. His substitute in the textbook committee was Professor Robert Livländer. Priority in the publishing of textbooks was given to those titles that were expected to be used by greater numbers of students and to the subjects for which there were no appropriate foreign language textbooks available. The Academy also addressed the Ministry of Education with a wish to participate in the selection and publication of these science and popular science books that the state intended to purchase for schools. The General Assembly of the Academy in general agreed with the positions taken by the textbook committee. Four textbooks submitted by faculty members of TUT were included in the list of books to be published first. All manuscripts passed through a scrupulous and thorough reviewing procedure. Armin Öpik, as a reviewer, expressed strong criticism towards the use of terms by Professor Jaan Kark in his manuscript for the mineralogy textbook Mineraloogia opperaamat (1940), while additional amendments on his part were made by the language editor Jaan Roos. At the time Öpik himself was preparing a three-volume geology textbook for publication. The fate of Arvo Veski's manuscript titled Puitehituse käsiraamat ('The handbook of wood construction,' 1940) was left in the hands of Leo Jürgenson, head of the Building Science and Engineering Laboratory at TUT. The committee subsequently continued to follow strict criteria they had laid down for matters of language, insisting on unconditional observance of linguistic rules.

Altogether five books were published under the auspices of the Committee for University Textbooks at the Estonian Academy of Sciences. Five successive titles, reviewed and prepared for the press by the committee, came out in 1940, among them the abovementioned building handbook by Veski, this time published by 'Teaduslik Kirjastus'. At the same time, technology textbooks edited with keen attention to linguistic detail served as a significant contribution to the development of the Estonian technical language. On the whole, from 1918 to 1940 the output of technology books printed in Estonia reached about seven hundred titles, and the number of individual technology journal titles on a variety of subject areas issued within the same period exceeded 30 . 


\section{The past half-century}

The first post-war decade and a half had passed without leaving any noteworthy tracks on the development of Estonian lexicon of technical terms. It would be false to say that the regulation of terminology was fully abandoned. However, the process remained at a rather primitive and superficial level, failing to get to the bottom of the issue. Borrowing from other languages and direct copying of foreign linguistic forms were common methods. Creativity was rarely applied, not to mention opportunities for a wider application of expression available in the language. The prevailing attitude to language had brought to the fore the focus on language purism, whereas seeking greater variety of opportunities for expression were left in the background, and this only caused further disequilibrium. A new surge in linguistic creativity could be detected in the 1960s. At this point, in the development of technology lexicon more attention was paid, among other things, to the requirements of technical language as well as to a more knowledgeable and versatile application of resources available in the Estonian language. This was the time when Jürgenson engaged himself in language problems for the second time. He never stopped insisting that terminology had to be precise, unequivocal and its use consistent. Jürgenson also argued that the spreading of well-formulated principles for terminology regulation by means of glossaries of technical terms was of major importance. Clearly defined and systematic terms facilitate learning and teaching alike. International technical terms shared by multiple languages are material components of terminology, yet in the light of the normativity and modernity of a language due attention should also be devoted to linguistic forms and the stock of expressions in the Estonian language.

\section{Final considerations}

Who should be responsible for the regulation of technology lexicon? A linguist may fail to grasp the meaning of a term, whereas a researcher of a specific field is inclined to fall in a habitual pattern. The person to make decisions ought to have a broader outlook on life. The importance of knowing the substance of a term is further emphasized by the actual fact that the two great Estonian linguists Wiedemann and Veski were also natural scientists. Furthermore, while unequivocal terminology is most notably required in teaching, regulation of technology vocabulary should remain the responsibility of the University of 
Technology. Sound reasoning combined with avoiding needless rushing at this point is a firm basis to rely on.

Since Estonia regained independence, a great number of terminological dictionaries have been published, with faculty members of the Tallinn University of Technology as authors or co-authors. Of the nearly one hundred glossaries of technical terms in total, half pertain to the sphere of informatics and information technology, followed by technological sciences and economics.

\section{References}

Aarma, L. (2009), 'Eestikeelse pôllumajandusliku kirjanduse algus ja esimene póllumeeste nóuandja-käsiraamat / Der Beginn estnischsprachiger landwirtschaftlicher Literatur und der erste Ratgeber für Landwirte' Rahvusvaheline konverents "Eestija vôórkeelne trükis Eesti- ja Liivimaal 1801-1917” 29. ja 30. oktoobril 2009 Eesti Kirjandusmuuseumis: Ettekanded / "Estnisch-und fremdsprachige Druckschriften in Estund Livland 1801-1917“29. bis 30. Oktober 2009, Tartu: Eesti Kirjandusmuuseum, pp. 27-28.

Bölau, K. (1938), ‘Ääremärkusi tehniliste oskussónade kohta,’ Tehnika Ajakiri, no. 5, pp. 103-108.

Deemant, H. (1976), 'Keemia eestikeelses koolikirjanduses enne 1917. a.,' in Ü. Lumiste (ed.) Teaduse ajaloo lehekülgi Eestist. II kogumik, Tallinn: Valgus, pp. 197-216.

Hacker, G. (1920), 'Oskussônade loomisest,' Eesti Tehnika Seltsi Ajakiri, no. 19, p. 242.

Jürgenson, L. (1975), 'J. V. Veski póhimôtete rakendamine tehnika oskussônavara soetamisel,' in Emakeele Seltsi aastaraamat, Tallinn: Eesti Raamat, nos. 19-20, pp. 33-37.

Kiesel, O. J. (1922), Katseline keemia koolidele, Tallinn: K.-ü. Kool.

Kübarsepp, J. \& Mägi, V. (2011), 'Eesti teaduskeele arendamine ja kasutamine tehnika, tehnoloogia ja majanduse valdkonnas,' Eestikeelne ülikool: 3. detsembril 2009 peetud terminoloogiakonverentsi ettekanded, Tartu: Tartu Ülikooli Kirjastus, pp. 36-45.

Kull, R. (1987), 'Leo Jürgenson ja tehnikakeel,' Ehitus ja Arhitektuur, no. 2, pp. 29-32. (1992), 'Professor Leo Jürgenson tehnikakeele edendajana,' in V. Mägi (ed.) Insenerikultuur Eestis I, Tallinn: TTÜ kirjastus, pp. 63-71.

Lang, J. (1976), 'Eestikeelsed füüsikaópikud ja oskussônavara aastail 1855-1940,' in Ü. Lumiste (ed.) Teaduse ajaloo lehekülgi Eestist. II kogumik, Tallinn: Valgus, pp. $137-150$.

Lumiste, Ü. (1968), 'Matemaatika Eestis XVII ja XVIII sajandil,' in Ü. Lumiste (ed.) Teaduse ajaloo lehekülgi Eestist. I kogumik, Tallinn: Valgus, pp. 73-91. 
Mägi, V. (1987), 'Professor Evald Malteneki teaduslikust ja óppetegevusest,' Tallinna Polütehnilise Instituudi Toimetised, no. 650, pp. 12-23.

_ (1989), 'Eesti Tehnika Seltsi Ajakiri: Eesti tehnikaajakirjanduse radadelt,' Tehnika ja Tootmine, no. 8, pp. 42-44.

- (2001), 'Tehnika ja tehnikaraamat Eestis,' in T. Tender (ed.) Raamatu osa Eesti arengus, Tartu: Eesti Raamatu Aasta Peakomitee, pp. 274-294.

(2007), 'From the $17^{\text {th }}$ century to the present-day in Estonia: evolution of exact and natural sciences,' in The Global and the Local: the History of Science and the Cultural Integration of Europe: Proceedings of the $2^{\text {nd }}$ International Conference of European Society for the History of Science, Cracow: European Society for the History of Science, pp. 920-924.

Sirk, V. (1983), Kutseharidus Eestis 19. sajandi algusest 1917. aastani, Tallinn: Valgus.

Veiderma, M. (2006), 'Eesti Teaduste Akadeemia ülikooliōpikute väljaandjana 19381940,' Akadeemia, no. 3, pp. 586-592.

Vahur Mägi obtained his Ph.D. in the History of Culture from the University of Tallinn in 2004. He is senior researcher at the Library of Tallinn University of Technology. His current research interests are the history of technology and technical education in Estonia and engineering culture in Estonia. 